\title{
Alternative of Innovative Financing Planning in Administration of Slum Areas in Bandung, West Java, Indonesia
}

\author{
Poni Sukaesih Kurniati \\ Department of Government Science, \\ Universitas Komputer Indonesia \\ Bandung, Indonesia
}

\author{
Suryanto \\ Department of Business Administration, \\ Universitas Padjadjaran \\ Bandung, Indonesia
}

\begin{abstract}
This study aims to identify innovative financing sources in structuring slums in the city of Bandung, West Java Province, Indonesia. This research method is explorative qualitative. This research is included in a descriptive exploratory study with a qualitative approach. The research data used consists of primary and secondary data. Primary data was obtained through interviews and observations, while secondary data was obtained through literature studies. The results showed that the sources of financing used in managing slums in the city of Bandung were obtained through three sources of financing. The three sources include financing through income, financing through debt, and financing through wealth. Income financing includes betterment levies and development impact fees. Debt financing includes bonds, excess condemnation, and linkage. While financing through wealth includes joint ventures (public-private partnership), concession, corporate social responsibility, and non-governmental organizations.
\end{abstract}

Keywords- innovative financing, non-conventional financing, slums

\section{INTRODUCTION}

Innovative financing planning is a development financing plan that emphasizes cooperation between government institutions and business entities [1]. Innovative financing planning needs to be done because of the limited regional budget and expenditure (APBD). The local government is obliged to fulfill the share of the needs of its citizens, including addressing the problem of slums. The problem of slum settlements is a problem of settlement management which is closely related to the provision of housing for weak economic communities which always arise in developing cities [2].

Meeting the needs of homes in residential areas is an issue that continues to emerge today. In most countries, almost a large part of the city's population cannot afford to buy decent housing and even insists on living in small housing units, living on the edge of the city, away from work. The construction of housing and settlements according to Budiharjo (1997) is essentially to realize decent living conditions (livable), safe, comfortable, peaceful and sustainable [3].

Lack of housing supply usually occurs for low-income people. This community group is the population that is least able to pay the price of land and the increasing construction costs of the house [4]. While markets cannot provide affordable housing in locations where the poor can get jobs and other services.

So, because the existing housing is not affordable for the poor, this is where the importance of housing finance is. The availability of choices to increase the ability to buy a house that meets the standards in accordance with the context of urbanization is very necessary. In addition, various housing finance mechanisms are also needed that can be reached by the poor. The role of housing finance is also important considering that the government is also increasingly less concerned with direct housing provision, and applies more as a provider, including by providing alternative financing to provide more choices for people in the city [5].

Housing as one of the basic needs, up to now most of it is provided independently by the community either to build their own or independent rental to other parties [6]. The main constraints faced by society, in general, are the affordability of home financing. On the other hand, housing loans from banks require various requirements that not all parties can get easily and interest rates are not cheap [7].

When building housing and settlements in the city of Bandung, the most important element that must be considered is the ability to provide decent housing and settlements. But it is realized that the longer the land for settlements is not increasing and is inversely proportional to the growing population of Bandung City. So the Bandung City government tries to meet the needs of residential land without making Bandung City a dense slum area. Slums are neighborhoods where conditions of residence or shelter are crowded, the size of the house is not proportional to the number of residents [8].

Slums are a problem faced by almost all cities in Indonesia and even large cities in other developing countries. The root of the problem of slums is more complex, namely 
due to the omission (negligence) of the development of urban marginal spaces; weak city management; the absence of an introduction to the needs (housing needs assessment) and a full and participatory housing stock evaluation; and the lack of development of a housing delivery system [9].

Housing procurement is an alternative to solving the problem of housing needs that often arise accompanying the development of a city. The pattern of housing procurement in meeting these needs can be done, both with new construction patterns and by rejuvenating a housing environment that has been developed (renewed) [10]. In the new construction pattern, generally, a housing procurement is done with the previous pattern. Whereas in the renewing pattern, housing procurement is carried out on the area/land that has been developed/built.

There is a difference between the pattern of new development and the rejuvenation of slums. In the new development pattern, housing development starts with the will/initiative of the actors. Whereas in the rejuvenation of slums there are several interested parties. The interested parties are those who are directly involved and others who often clash and differ from the interests and needs of the people who inhabit the settlement.

Handling settlements with rejuvenation as part of a housing procurement process is rarely seen as an alternative in procurement. Ironically, slum settlements are actually a housing problem that is always present in every city in quite a large number and is ready to wait to be handled immediately, given the clear and existing target group.

Urban rejuvenation can be used as a solution for urban area management and eradication of slums, especially in the city of Bandung. Structuring the slum area requires substantial costs. The Regional Revenue and Expenditure Budget (APBD) will not be able to provide funding for the arrangement of the Kumu area. Financial assistance is needed from other parties, such as the central government, provincial government, and other parties.

The limited conditions of the regional budget require regional governments to be able to find alternative sources of financing for regional development [11]. The regional government must be able to plan innovative financing so that the implementation of slum areas can be implemented without too much burden on the regional budget. There are several possibilities that can be taken by each region, namely by issuing regional bonds or optimizing the participation of the business community.

Based on previous research that sources of funds outside the APBD that can be used for financing development can be done through regional bonds and cooperation between the government and the private sector. sector through the PublicPrivate Partnership (PPP) scheme [12]. Other researchers suggest that non-APBD funding sources can be sourced from Corporate Social Responsibility (CSR) [13].

\section{METHOD}

This study uses a qualitative approach with a type of explorative descriptive research. The data source used consists of primary and secondary data. Primary data collection techniques are carried out through interviews and surveys, while secondary data is obtained through literature studies related to financing the construction of slum areas.

Data analysis techniques are carried out by doing a description of the object under study with an analysis. Descriptive data analysis is intended as an attempt to explain parts of the entire data through clarification and categorization so that a series of more systematic descriptions can be prepared.

\section{RESULTS AND DISCUSSION}

Regional development is aimed at creating communities in the area to be fair, prosperous and prosperous. Development is carried out in accordance with the established medium and long-term development plans. One of the developments that are currently the center issue is the construction of slum housing and settlements.

National policies targeting the $0 \%$ slum area by 2019 are based on the SDGs agenda through Presidential Regulation No. 59 of 2017. In the Attachment to the Presidential Regulation, a target has been set for the slum arrangement which one of the implementing agencies is the city government.

The Bandung City Government has arranged the slum area according to the Bandung City RPJMD 1st mission, but there is no standardization from the target side. Because the target has not been standardized, the implementation of slum arrangement refers to national policy. The arrangement of urban slums is focused on providing decent and affordable housing and public spaces for the entire community [14].

In general, there are 3 (three) patterns of handling to improve the quality of settlements

(1). Restoration

For repairs and/or rebuilding of housing and settlements into habitable housing and settlements. Repairs to buildings, facilities and/or public utilities carried out without fundamental and partial changes.

(2). Rejuvenation

To realize the condition of better residential, residential and residential buildings to protect the safety and security of residents and surrounding communities. Through complete dismantling and positioning of buildings, facilities and/or public utilities.

(3). Resettlement 
To realize the condition of better residential and residential buildings to protect the safety and security of residents and the community. This is done by moving affected people to locations with classifications

Based on the Prevention and Improvement of Urban Slum Quality Plans (RP2KPKP) document, a total of 121 out of 151 villages in Bandung have been stipulated in the Mayor's Decree including in the slums. Based on the RP2KPKP document from 121 villages there are 15 villages that are priority areas. As for the existing conditions from the results of the RPLP review 15 Priority areas, there are 11 types of programs that need to be financed. Of the 15 new priority areas, there are 4 RPLP data that can be assessed based on the availability of data in Development Planning, Research and Development Agency (BAPPELITBANG), including Cirangrang, Sekejati, Pasir Impun, and Sukahaji

The RPLP has reached the detail level of DED (Detail Engineering Design), the scope of the newly designed handling pattern for the restoration pattern with a financing list is only prepared for construction activities only. It is estimated that the total financing needs of slum area management from non-conventional sources reach Rp. 1.1 trillion

Table 1. Estimated Need for Financing Slum Area Arrangement

\begin{tabular}{|c|c|c|c|c|}
\hline No & Program & $\begin{array}{c}\text { Estimate } \\
\text { d costs }\end{array}$ & Description & Work unit \\
\hline 1 & $\begin{array}{l}\text { Revitalizi } \\
\text { ng Slums }\end{array}$ & $\begin{array}{ll}\text { IDR } & 1 \\
\text { trillion } & \end{array}$ & $\begin{array}{l}\text { Target 16 Village: } \\
\text { Ciroyom, } \\
\text { Nyerengset, } \\
\text { Sukabungah, } \\
\text { Pajajaran, Arjuna, } \\
\text { Cigondewah, } \\
\text { Rahayu, Cempaka, } \\
\text { Husein Sstranegara, } \\
\text { Babakan, Antapani } \\
\text { Wetan, Babakan } \\
\text { Surabaya, Binong } \\
\text { Jati, Taman Sari, } \\
\text { Babakan Ciamis, } \\
\text { Cigondewah Kidul }\end{array}$ & $\begin{array}{l}\text { Department } \\
\text { of Housing, } \\
\text { Settlements } \\
\text { and Parks }\end{array}$ \\
\hline 2 & $\begin{array}{l}\text { Home for } \\
\text { decent } \\
\text { living }\end{array}$ & $\begin{array}{l}\text { IDR } 100 \\
\text { billion }\end{array}$ & 4.421 units & $\begin{array}{l}\text { Department } \\
\text { of Housing, } \\
\text { Settlements } \\
\text { and Parks }\end{array}$ \\
\hline
\end{tabular}

There are at least 8 potential sources of funding for development activities known in Indonesia, including from the central government, provincial government, district/city government, local banks, international credit/loans, bilateral or other donors, NGOs, other private sectors. However, in the activities of structuring slums, the funding sources used generally come from the funds of the central government, provincial governments and district/city governments and the private sector.

The forms of financing schemes from each funding source include:

a. Central government

(1). State Budget
(2). Grant

(3). Foreign loans

b. Provincial government

(1). Provincial grant

(2). Loan

c. District/City Government

(1). APBD

(2). SILPA

(3). Reserve fund, revolving fund

d. Donor

(1). Micro-credit loans

(2). Grant

e. Private

(1).Bank loans (commercial, micro-credit, revolving funds)

(2). Private investment, including PPP, PSP

(3). Special forms of private investment (rent, BOT), grants, CSR.

In the slum area structuring activities, the financing schemes used are APBN, APBD-P, Bandung City APBD and CSR (Private TJSL). The Bandung City Government has also included the PPP Project for Revitalization of Slum Areas and Rutilahu. The main problem with conventional financing sources is their very limited capacity

Conventional funding sources are obtained from the government, which are derived from government budgets such as APBN / APBD, taxes, and levies. Whereas nonconventional financing sources are obtained from a combination of government, private and community funds. If the financing of development uses funding sources from the government, both APBN and APBD, then only as a small allocation.

The following is the allocation of funding sources from the allocation of conventional funding sources.

Table 2. Allocation of Conventional Funding Sources

\begin{tabular}{|c|l|}
\hline $\begin{array}{c}\text { Source of Conventional } \\
\text { Financing }\end{array}$ & \multicolumn{1}{c|}{ Problems } \\
\hline APBN & $\begin{array}{l}\text { The APBN can only finance 8.7\% of the } \\
\text { total needs in the infrastructure sector } \\
\text { until 2019 (total needs reach IDR 5,000 } \\
\text { trillion). 41.3\% of infrastructure projects } \\
\text { still rely on injections from the state } \\
\text { budget }\end{array}$ \\
\hline APBD & $\begin{array}{l}\text { The APBD is only able to cover 6\% of } \\
\text { priority infrastructure project financing } \\
\text { until the end of RPJMD 2013-2018 } \\
\text { (Total Needs reach 55.4 Trillion) }\end{array}$ \\
\hline
\end{tabular}

There are limited sources of conventional funds in financing development, but financing needs are very large. Therefore, there is a need for innovative financing sources to finance slum development. 
There are 3 types of innovative financing sources of development originating from non-conventional financing schemes, namely: (1) Financing through income consisting of repair fees (betterment levies and development impact fees); (2) financing through debt consisting of bonds, excess condemnation, and linkage; and (3) Financing through wealth consisting of joint ventures, concessions, CSR, and community self-help.

\section{A. Financing through Revenue}

Sources of financing for innovation through revenue are a type of non-risk financing source [15]. However, this funding source is relatively limited. The following includes sources of financing through income, including:

(1). Repair Levies (Levies Betterment).

Betterment levies are capital charges intended to cover/finance capital costs from infrastructure investments. In reality, this type of levy is relatively less widely used. The main purpose of imposing these types of levies is to encourage people who benefit from the existence of public infrastructure in order to share the costs.

Thus, these levies are charged directly to those who benefit directly from the improvement of the public infrastructure. The basis for the imposition can be based on the number of areas or based on the estimated value of benefits obtained

(2). Development Impact Fees.

Development impact fees are paid by developers to local governments or regional companies as compensation for the impact caused by new developments, for example, the construction of a housing complex, which has an impact on the need for new infrastructure outside the complex in question.

The main objective of the imposition of this levy is to cover the costs associated with the construction of infrastructure needed as a result of the development in a location, for example, housing complex, industry, and so on. These levies are usually imposed when the building permit (IMB) is issued by the local government

\section{B. Financing Through Debt}

Development, especially in slums, requires a very large source of financing. To carry out the development, alternative financing is needed in the form of regional loans (debt). In the Government Regulation of the Republic of Indonesia Number 5 of 2005 concerning Regional Loans, regional loans are all transactions that result in regions receiving from other parties a sum of money or valuable benefits so that the area is burdened with the obligation to repay, not including short-term loans that commonly occur in trade.
Regional loan sources come from the central government, donor countries through the central government (two-step loans), capital markets and community savings. Regional loans are needed to finance various needs and provision of facilities. In regional loans, the government sets the cumulative maximum limit of local government loans by taking into account the state and forecast of national developments. The cumulative maximum loan limit does not exceed $60 \%$ of the relevant Gross Domestic Product [16].

The following are sources of financing through debt, including:

(1). Bond

Basically, bonds are also a form of loans made by the government and regional companies to finance infrastructure investments. Sources of bond funds are obtained through fund mobilization in the capital market.

(2). Excess Condemnation

Excess condemnation is an indirect infrastructure financing method, in which a number of lands are set aside for infrastructure development, and a number of others are given to private developers for commercial development. In return, the developer is obliged to build the infrastructure needed. This instrument is commonly used to rebuild slum areas, where through this instrument the provision of urban infrastructure in the area can be carried out without being financed by the public sector.

(3). Linkage

Developers are required to provide and finance similar infrastructure in other less desirable areas, in order to get development approvals in the areas they want. This kind of method in Indonesia has begun to be known, especially with regard to housing development, where developers are required to build simple housing as compensation for giving permission to build luxury housing.

\section{Financing through Wealth}

The following includes sources of financing through wealth, including:

(1). Joint Venture - PPP

Joint ventures are the collaboration between the private sector and the government (public-private partnership) where each party has a balanced position in the company concerned. The main objective of this collaboration is to integrate the advantages of the private sector, such as capital, technology, and management capabilities, with the advantages of the government sector, for example, the sources, authority, and trust of the public.

\section{(2). Concession}


Some examples of concessions are: service contracts, management contracts, rental contracts, BOT (Build, Operate, and Transfer), BOO (Build, Operate, and Own), and investment (the private sector takes overall company control by buying all government assets).

(3). CSR (TJSL)

Corporate Social Responsibility (CSR) in Indonesian is known as corporate social responsibility. In Chapter V Article 74 of Law Number 40 of 2007 concerning Limited Liability Companies regulates Social and Environmental Responsibility, whereby the Company which carries out its business activities in the field and/or related to natural resources is obliged to carry out Social Responsibility and The environment.

(4). Non governmental

Sources of public funds are all kinds of funding sources that are based on the assets/personnel of the surrounding community to develop the surrounding area.

\section{CONCLUSION}

From the description above it can be concluded that the financing of infrastructure development in the region can be done from several sources. The sources of financing, among others, come from the original sources of regional revenues contained in the APBD and from non-APBD financing or a combination of APBD and non-APBD. Infrastructure financing can be grouped into three financing models, namely; (1) conventional models, (2) transitional models, and; (3) ideal model (budget sustainability). To realize the ideal model it is necessary to work together with various parties synergistically by considering three aspects, namely: partners to partner, forms of cooperation, and implementation period. Seeing the condition of infrastructure in the city of Bandung that is not optimal, local governments need to increase the ideal financing model. However, the central government also needs to conduct special interventions, for example through Special Allocation Funds, Deconcentration Funds, or other funding assistance.

\section{REFERENCES}

[1]. Badu, Edward, et al. "Analysis of strategic issues underpinning the innovative financing of infrastructure within developing countries." Journal of Construction Engineering and Management 139.6 (2012): 726-737.

[2]. Burra, Sundar. "Towards a pro-poor framework for slum upgrading in Mumbai, India." Environment and Urbanization17.1 (2005): 6788 .

[3]. Budiharjo, Eko. Sejumlah Masalah Permukiman Perkotaan.Bandung: Alumni. (1997).

[4]. Abiko, Alex, et al. "Basic costs of slum upgrading in Brazil." Global Urban Development Magazine 3.1 (2007).

[5]. Gupta, Devendra B. Urban housing in India. Vol. 1. World Bank, (1985)..

[6]. Myers, Dowell, John Pitkin, and Julie Park. "Estimation of housing needs amid population growth and change." Housing Policy Debate 13.3 (2002): 567-596.

[7]. Suryanto, and Budiman Rusli. "Analysis of economy aspects in the policy on establishing housing and settlement in West Java,
Indonesia." International Journal of Trade and Global Markets 10.1 (2017): 91-98.

[8]. Field, Erica. "Property rights and investment in urban slums." Journal of the European Economic Association 3.2-3 (2005): 279-290.

[9]. Hasrul Rizka1, Agus Purwoko, dan Rujiman. Perencanaan Penanganan Kawasan Pemukiman Kumuh di Kelurahan Tanjung Tiram Kabupaten Batubara, Serambi Engineering, Volume III, Edisi Khusus, Februari (2018)..

[10]. Shankar, Sharada, and Ann Klassen. "Influences on fruit and vegetable procurement and consumption among urban AfricanAmerican public housing residents, and potential strategies for intervention." Family Economics and Nutrition Review 13.2 (2001): 34.

[11]. Basri, Faisal H. Tantangan dan Peluang Otonomi Daerah, Jurnal Pada Lintasan Ekonomi, Volume XVII, Nomor I, Juli-Desember 2000, Lembaga Penerbitan dan Puublikasi Ilmiah Fakultas Ekonomi Universitas Brawijaya, Malang (200).

[12]. Elmi, Bachrul. Analisa Obligasi Untuk Membiayai Pembangunan Daerah (Municipal Bonda) Kasus Pemda Propinsi Jawa Barat. Working Paper (2005)..

[13]. Okta, Dewi dan David Kaluge, Analisis Peuang obligasi daeran sebagai sumber alternatif pembiayaan Derah, Journal Indonesia Apply of Economics, 5. 2, (2011): 157-171.

[14]. Marmot, Michael, et al. "Closing the gap in a generation: health equity through action on the social determinants of health." The lancet 372.9650 (2008): 1661-1669.

[15]. Nice, David C. "The impact of state policies to limit debt financing." Publius: The Journal of Federalism 21.1 (1991): 69-82.

[16]. Isunju, John Bosco, et al. "Financing of sanitation services in the slums of Kampala and Dar es Salaam." Health 5.4 (2013): 783-791. 